\begin{tabular}{c} 
Brazilian Journal \\
of Chemical \\
Engineering \\
\hline
\end{tabular}

ISSN 0104-6632

Printed in Brazil

www.abeq.org.br/bjche

Vol. 25, No. 04, pp. 723 - 728, October - December, 2008

\title{
THE ROLE OF PHENOLS FROM BAGASSE VACUUM PYROLYSIS BIO-OIL IN CUPPER SULFURED ORE FLOTATION
}

\author{
L. E. Brossard ${ }^{2}$, A. L. Beraldo ${ }^{1 *}$, L. A. B. Cortez ${ }^{1}$, L. E. Brossard $\mathrm{Jr}^{2}$, \\ E. D. Maury ${ }^{2}$ and C. O. Brossard ${ }^{2}$ \\ ${ }^{1}$ Faculdade de Engenharia Agrícola, FEAGRI, UNICAMP, Phone: +(55) (19) 3521-1030, Cidade Universitária \\ Zeferino Vaz, Barão Geraldo, Cx. P. 6011, CEP 13083-875, Campinas - São Paulo, Brazil. \\ E-mail: beraldo@feagri.unicamp.br \\ ${ }^{2}$ Facultad de Ingeniería Química, Universidad de Oriente Sede Mella, \\ Ave. Las Américas s/n, Ampliación de Terraza, Cx. P. 90 600, Santiago de Cuba.
}

(Received: January 15, 2006 ; Accepted: February 05, 2008)

\begin{abstract}
Vacuum pyrolysis bagasse bio-oil collected in a series of sequential fractions was analyzed for total percentage of phenols and levoglucosan components. It was established that the ratio total phenols- tolevoglucosan could be used as an indicator of the performance of alkaline solutions of bio-oil fractions (SABO) when they are used as foaming agents to benefit flotation of sulfured cupper minerals. A high total phenol-to-levoglucosan ratio results in high percentages of $\mathrm{Cu}$ in cupper flotation concentrates, $\mathrm{L}_{\mathrm{Cu}}$. A closer look at the role of individual phenols reveals that p-cresol is the main phenol, although not the only one, responsible for the observed behavior. Additionally it was noted that rather high doses of these foaming agents must be used to obtain desirable results in flotation processes. A production cost estimate allows consideration of SABO as an alternative to others commercial foaming agents, especially if an optimization study reduces doses of SABO.

Keywords: Pyrolysis; Bio-oil; Phenols; Cu flotation.
\end{abstract}

\section{INTRODUCTION}

Since the beginning of last century, dry distillation of wood has been industrially exploited to obtain charcoal as the main solid product. This thermal decomposition of wood, and in general of any lignocellulosic material (slow pyrolysis), is accompanied by a liquid phase composed of water and a mixture of soluble and insoluble organic compounds. The water-insoluble compounds are mainly a mixture of partially polymerized phenols and other high-molecular-weight organic compounds (pyrolysis tar or bio-oil) while low-molecular-weight carboxylic acids and neutral compounds including carbohydrates constitute the main water-soluble components (Yorgun et al., 2001). By the second half of twentieth century, new pyrolysis processes were developed with the aim of obtaining higher yields of low-molecular-weight compounds in bio-oil. Two approaches were followed: fast pyrolysis (Diebold and Scahill, 1988; Diebold and Bridgwater, 1999) and vacuum slow pyrolysis (Pakdell et al., 1994; Roy et al., 1997; Boucher et al., 2000). The biooil fraction obtained from these processes is currently used as raw material for different applications such as fuels (Radlein et al, 1996; Shadix and Tenison, 1998; Radlein, 1999), formaldehyde resins (Chum and Kreibich, 1993), $\mathrm{NO}_{\mathrm{x}}$ and $\mathrm{SO}_{\mathrm{x}}$ emission reduction (Zhou et al., 1997) etc.

Conventional slow pyrolysis does not give high yields of liquid organic substances (bio-oil and pyroligneous acid) nor does it avoid further

*To whom correspondence should be addressed 
condensation, polymerization and cracking of organic constituents. As a result of such experimental conditions, the organic fraction obtained is a complex mixture of high-molecularweight substances of restricted value for most applications. On the other hand, in vacuum pyrolysis as well as in flash pyrolysis, condensable gases are quickly removed from the hot zone of the reactor, preserving the identity of original compounds and therefore yielding simple mixtures.

Vacuum slow pyrolysis of sugar cane bagasse has been studied in a search for less degraded liquid products (Brossard et al., 2000; Penedo, 2000). This liquid fraction is rich in two components: levoglucosan and phenols (Lomax et al., 1991; Penedo, 2000). According to exploratory tests conducted by authors of this article, both types of substances seem to have great importance in the foaming behavior of alkaline bio-oil solutions when they are used in mineral ore flotation.

Alkaline solutions of bio-oil from slow pyrolysis of bagasse have been used as foaming agents in sulfured copper ore flotation (Brossard and Cortez, 1997). At that time the hypothesis that phenol components were accountable for observed results, was advanced. According to this, a pyrolysis process that would not promote additional thermal changes in the primary bio-oil should be a better option for the same purpose.

The present work deals with the use of sugar cane bagasse bio-oil from vacuum pyrolysis, in the form of alkaline solution for the sulfured copper ore flotation process. Unfortunately, a careful literature search did not show reports regarding the use of bio-oil as foaming agents for sulfured $\mathrm{Cu}$ or any other minerals.

\section{MATERIALS AND METHODS}

\section{Vacuum Pyrolysis Experiments}

Vacuum pyrolysis laboratory installation was furnished of three ice-cooled flasks interconnected and that were connected to the gas exit of an electrically heated pyrolysis reactor in such a way that sequential collection of three fractions (Fractions I, II, and III) was possible under each experimental condition. These fractions constitute three condensates originating in the reactor and used in this work.

All experiments were carried out under vacuum at $20 \mathrm{kPa}$ with air-dried integral bagasse (12\% moisture content, d.b.) and pressed into briquettes of different apparent densities. The final pyrolysis temperature was uniformly maintained at $425{ }^{\circ} \mathrm{C}$ during 2 hours. Experimental conditions adopted for this study are shown in Table 1.

Heating speeds as well as bagasse density levels were chosen in order to confirm the hypothesis that under slow pyrolysis conditions in moderate vacuum, an increase in heating speed and relatively low-density-bagasse briquettes, should yield bio-oils with higher phenol content. Yields of total solid (charcoal), liquid (water and organics) and gaseous products are shown in Table 2.

The liquid fractions from the selected pyrolysis conditions were analyzed for total phenols $(\mathrm{F})$ and levoglucosan (L) by means a Hewlett-Packard 5890 Series 11 gas chromatograph connected to a Hewlett - Packard 598913 mass spectrometer. Results, including $\mathrm{pH}$ of all fractions, are shown in Table 3.

\section{Flotation Experiments}

Experiments were conducted by means of a discontinuous bench installation furnished with a ball mill with a processing capacity of $0.8 \mathrm{~kg}$ mineral pulp in $0.8 \mathrm{~kg}$ water and a Denver flotation machine $(2.5 \mathrm{~L}$ mineral pulp capacity). Sulfured cupper mineral used in bench tests was analyzed (see Table 4) with a UNICAM ATI atomic absorption spectrometer.

\section{Flotation Reagents}

Potassium amyl xanthate was used as collector and $\mathrm{pH}$ was regulated in accordance with current industrial practice at Mina Grande El Cobre, with carbide ash, which is the solid residue of calcium carbide hydrolysis in acetylene gas production. Foaming agents were prepared from the tar fractions in Table 3 or from pure phenols mixtures by adding $\mathrm{NaOH} 1 \mathrm{M}$ solution up to neutralization point. In this way the reddish-brown aqueous solutions with $22 \%$ average solid content were prepared.

\section{Flotation Conditions}

All flotation parameters selected, except for flotation time and further processing of the foams collected, are currently used in industry.

- Foaming agent-to-mineral mass ratios $\left(\mathrm{g} \cdot \mathrm{ton}^{-1}\right)$ : 50 and 200.

- $55 \%$ mineral pulp particles $<0.074 \mathrm{~mm}$.

- Pulp pH adjusted to 10.6.

- Liquid-to-solid ratio $\left(\mathrm{mLg}^{-1}\right): 3.3$.

- Flotation time: 8 minutes.

- Foams collected were not further processed. 
Table 1: Conditions for vacuum slow pyrolysis ( 2 hour pyrolysis time)

\begin{tabular}{|l|c|c|c|}
\hline Variables & Condition 1 & Condition 2 & Condition 3 \\
\hline $\begin{array}{l}\text { Heating speed } \\
\left({ }^{\mathrm{O}} \mathrm{C} \cdot \mathrm{min}^{-1}\right)\end{array}$ & 12.4 & 5.4 & 12.4 \\
$\begin{array}{l}\text { Apparent density } \\
\left(\mathrm{kg} \mathrm{m}^{-3}\right)\end{array}$ & 263.8 & 263.8 & 362.4 \\
\hline
\end{tabular}

Table 2: Yields of charcoal, pyrolytic liquids and gaseous products from vacuum slow pyrolysis of bagasse briquettes

\begin{tabular}{|c|c|c|c|}
\hline & \multicolumn{3}{|c|}{ Yields (\% d.b.)* } \\
\hline Experimental condition & Charcoal & Pyrolytic liquids & Gaseous products \\
\hline 1 & 33.26 & 42.73 & 18.01 \\
2 & 28.41 & 53.14 & 22.64 \\
\hline
\end{tabular}

* Mean values of 5 replicates

Table 3: Total phenols and levoglucosan (\%) in bio-oil fractions I II and III (pH of each fraction)

\begin{tabular}{|l|c|c|c|c|c|c|c|c|c|}
\hline Experimental condition & \multicolumn{3}{|c|}{ 1 } & \multicolumn{3}{c|}{$\mathbf{2}$} & \multicolumn{3}{c|}{ 3 } \\
\hline Bio-oil fraction & I & III & III & I & III & III & I & III & III \\
Total phenols (F) & 13.3 & 9.5 & 10.1 & 9.3 & 7.2 & 4.1 & 10.2 & 8.6 & 7.9 \\
Levoglucosan (L) & 14.4 & 4.1 & 15.6 & 10.1 & 1.5 & 1.2 & 11.8 & 10.4 & 12.9 \\
F-to-L ratio & 0.92 & 2.32 & 0.65 & 0.92 & 4.8 & 3.42 & 0.90 & 0.83 & 0.61 \\
$\mathrm{pH}$ & 3.50 & 4.15 & 3.90 & 4.20 & 4.80 & 5.10 & 3.9 & 4.40 & 4.65 \\
\hline
\end{tabular}

Table 4: Composition of cupper mineral

\begin{tabular}{|c|c|}
\hline Component & \% \\
\hline $\mathrm{Ni}$ & 0.007 \\
$\mathrm{Co}$ & 0.005 \\
$\mathrm{Fe}$ & 11.03 \\
$\mathrm{Cu}$ & 2.27 \\
$\mathrm{Zn}$ & 0.013 \\
$\mathrm{Mn}$ & 0.126 \\
$\mathrm{Mg}$ & 1.04 \\
$\mathrm{Al}$ & 2.79 \\
$\mathrm{Ca}$ & 0.17 \\
$\mathrm{Cr}$ & 0.011 \\
$\mathrm{SiO}_{2}$ & 0.096 \\
$\mathrm{SO}_{4}^{2-}$ & 12.04 \\
$\mathrm{~S}^{2-}$ & 7.48 \\
\hline
\end{tabular}

\section{RESULTS AND DISCUSSION}

Bio-oil fractions obtained from vacuum pyrolysis experiments in order of increasing $\mathrm{F} / \mathrm{L}$ ratio are as follows: $2 \mathrm{FII}>2 \mathrm{FIII}>1 \mathrm{FII}>1 \mathrm{FI}, 2 \mathrm{FI}, 3 \mathrm{FI}>3 \mathrm{FII}>$ 1FIII $>$ 3FIII. If phenols as a whole play a decisive role in flotation with alkaline bio-oil solutions, the higher percentage in a given bio-oil fraction, the higher $\mathrm{L}_{\mathrm{Cu}}$ should be.

On the other hand, as observed in exploratory tests, levoglucosan content showed the opposite effect, making foam formation difficult and thus lowering $\mathrm{L}_{\mathrm{Cu}}$.
Therefore F-to-L ratio could be used as a predictor of the foaming capacity of alkaline bio-oil solutions prepared under different pyrolysis conditions.

In order to confirm this hypothesis a series of experiments were conducted using foaming solutions prepared from the bio-oil fractions shown in Table 3 by adding $\mathrm{NaOH}$ aqueous solution to them. Flotation experiments were designed with the double purpose of determining the order of efficiency of bio-oil fractions in alkaline solution and the influence of their doses in increasing $\mathrm{L}_{\mathrm{Cu}}$. Results from these tests are show in Table 5 
A two-way analysis of variance (ANOVA) of these results followed by a LSD test (Table 6) shows that factors dose and type of alkaline solution influence $\mathrm{L}_{\mathrm{Cu}}$, although the factor dose appears to be the more important. LSD tests applied to these results at $\alpha=0.05$ show that higher foaming agentto-mineral ratio $\left(200 \mathrm{~g} \mathrm{ton}^{-1}\right)$ and bio-oil fraction 2FII are the best levels for both factors. As shown in Table 7, alkaline solution from bio-oil fraction 2FII is significantly better as foaming agent than the rest of the solutions tested. It is also the alkaline solution from the bio-oil fraction with the highest phenol-tolevoglucosan ratio.

A closer look at Table 7 allows speculation about a possible decreasing order of effectiveness of the different alkaline solutions: 2FII $>2 \mathrm{FIII}, 1 \mathrm{FII}>1 \mathrm{FI}$, 3FI, 2FI $>3$ FII, 3FIII which follows the decreasing magnitude of the F-to-L ratio. Next step was to discover the role of individual phenols in bio-oil fraction mixtures.

For this purpose alkaline solutions of pure pcresol and of phenol mixed with p-cresol were prepared and compared to $2 \mathrm{FII}$ alkaline solution in relation to the $\mathrm{L}_{\mathrm{Cu}}$ increasing (see Table 8). Flotation experiments were conducted under the same conditions previously described. The results obtained for these model phenol solutions are shown in Table 9.

A two-way ANOVA and LSD tests applied to former results show that the p-cresol in bio-oil alkaline solution is the main component although not the only one responsible for the increase in $\mathrm{L}_{\mathrm{Cu}}$. Both factors (dose and foaming agent), have a statistically significant effect on $\mathrm{L}_{\mathrm{Cu}}$. From these results it is reasonable to conclude that $\mathrm{p}$-cresol is the most active component of bio-oil fraction 2FII.

Table 5: $\mathrm{L}_{\mathrm{Cu}}$ obtained with alkaline bio-oil solutions at two doses

\begin{tabular}{|c|c|c|c|c|c|}
\hline \multirow[t]{4}{*}{ Exp. No } & \multirow[t]{4}{*}{ Bio-oil } & \multicolumn{4}{|c|}{ Dose $\left(\mathrm{g} \mathrm{ton}^{-1}\right)$} \\
\hline & & \multicolumn{2}{|c|}{180} & \multicolumn{2}{|c|}{220} \\
\hline & & \multicolumn{4}{|c|}{$\mathbf{L}_{\mathrm{Cu}}$} \\
\hline & & $\mathbf{L}_{1}$ & $\mathbf{L}_{2}$ & $\mathbf{L}_{3}$ & $\mathbf{L}_{4}$ \\
\hline 1 & $1 \mathrm{FI}$ & 21.6 & 22.1 & 23.6 & 23.3 \\
\hline 2 & 1FII & 22.1 & 22.4 & 23.7 & 23.9 \\
\hline 3 & 1FIII & 19.0 & 20.0 & 21.3 & 22.0 \\
\hline 4 & $2 \mathrm{FI}$ & 20.9 & 22.0 & 23.5 & 23.2 \\
\hline 5 & $2 \mathrm{FII}$ & 24.1 & 24.5 & 25.3 & 25.7 \\
\hline 6 & 2FIII & 22.5 & 22.7 & 23.6 & 23.9 \\
\hline 7 & $3 \mathrm{FI}$ & 21.1 & 21.7 & 23.2 & 23.6 \\
\hline 8 & $3 \mathrm{FII}$ & 18.9 & 20.9 & 21.1 & 22.5 \\
\hline 9 & 3FIII & 16.3 & 15.2 & 21.6 & 20.8 \\
\hline
\end{tabular}

$* \mathrm{~L}_{1}$ and $\mathrm{L}_{2}$ are replicates of the same dose

Table 6: Two-way ANOVA for $\mathrm{L}_{\mathrm{Cu}}$ for types of alkaline solution and dose

\begin{tabular}{|l|c|c|c|c|c|}
\hline Source of variation & Sum of Squares & Df* & Mean Square & F-ratio & p-value \\
\hline (A) Dose & 36.69 & 1 & 36.69 & 118.67 & 0.0000 \\
(B) Type of & 109.36 & 8 & 13.67 & 40.87 & 0.0000 \\
alkaline solution & 13.58 & 8 & 1.69 & 5.08 & 0.002 \\
AB & 6.02 & 18 & 0.33 & & \\
Residual & 168.65 & 35 & & & \\
Total (corrected) & & & & & \\
\hline
\end{tabular}

*Degrees of freedom

Table 7: LSD tests for $\mathrm{L}_{\mathrm{Cu}}$ using different bio-oil alkaline solutions

\begin{tabular}{|l|c|}
\hline \multicolumn{2}{|c|}{ Method: 95 \% LSD } \\
\hline Contrasts & Difference \\
\hline 2FII-1FI & $* 2.25$ \\
2FII-1FII & $* 1.88$ \\
2FII-1FII & $* 4.33$ \\
2FII-2FI & $* 2.50$ \\
2FII-2FII & $* 1.73$ \\
2 F II-3FI & $* 2.5$ \\
2FII-3FII & $* 4.05$ \\
2FII-3FIII & $* 6.43$ \\
\hline
\end{tabular}

*Denotes significant difference 
Table 8: Composition of alkaline phenol model solutions

\begin{tabular}{|c|c|c|}
\hline Model solution & Composition & p-cresol \% \\
\hline PC & pure p-cresol & 100.0 \\
FC1 & p-cresol, phenol & 67.0 \\
FC2 & p-cresol, phenol & 80.0 \\
2FII bio-oil fraction & p-cresol, ethyl, and methoxy phenol & 30.0 \\
\hline
\end{tabular}

Table 9: $\mathrm{L}_{\mathrm{Cu}}$ for phenol model solutions

\begin{tabular}{|c|c|c|c|c|}
\hline & \multicolumn{4}{|c|}{ Dose $\left(\right.$ g ton $\left.^{-1}\right)$} \\
\hline & \multicolumn{2}{|c|}{180} & \multicolumn{2}{|c|}{220} \\
\hline & $\mathbf{L}_{1}$ & $\mathbf{L}_{2}$ & $\mathbf{L}_{3}$ & $\mathbf{L}_{4}$ \\
\hline Model solution & \multicolumn{4}{|c|}{$\mathbf{L}_{\mathrm{Cu}}$} \\
\hline PC & 21.13 & 20.35 & 22.95 & 22.65 \\
\hline $\mathrm{FC} 1$ & 13.32 & 13.72 & 20.77 & 20.89 \\
\hline $\mathrm{FC} 2$ & 16.19 & 16.6 & 21.07 & 21.12 \\
\hline 2FII & 21.91 & 21.85 & 23.86 & 23.66 \\
\hline
\end{tabular}

$* \mathrm{~L}_{1}$ and $\mathrm{L}_{2}$ are replicates of each dose

\section{CONCLUSIONS}

The foaming properties of alkaline pyrolysis bio-oil previously reported (BROSSARD and CORTEZ, 1997) are closely related to its phenol content and more specifically to its total phenol-to- levoglucosan mass ratio. When vacuum pyrolysis bio-oil is separated into fractions, this ratio varies and, consequently, a marked difference between the alkaline solutions prepared from them was noted. Bio-oil alkaline solutions with the highest total phenol-to-levoglucosan ratios are also the responsible for the highest $\mathrm{L}_{\mathrm{Cu}}$. Among the phenol constituents, p-cresol is the main responsible of this behavior. Although the fact that pure p-cresol shows results comparable to bio-oil 2FII fraction indicates that there exists some kind of synergistic effect with others bio-oil phenols For this reason it is more appropriate to consider total phenol-to-levoglucosan mass ratio as a predictor of good performance in increasing $\mathrm{L}_{\mathrm{Cu}}$.

It was also established that this foaming agent behaves better when added at 200 gton $^{-1}$ of mineral. Preliminary estimates of the production cost of a ton of alkaline bio-oil remain at around 400 USD dollars. Compared with those for other foaming agents, such as pine oil, this could be an attractive alternative, especially if an optimization study using lower SABO doses is conducted.

\section{ACKNOWLEDGEMENT}

The authors would like to thank FAPESP and CAPES for the financial support, provided for this work.

\section{NOMENCLATURE}

ANOVA Analysis of variance

Df: $\quad$ Degrees of freedom

F-ratio $\quad F$ test for variances

2FIII Bio-oil fraction III in experimental

condition 2

$\mathrm{L}_{\mathrm{Cu}} \quad$ Percentage of $\mathrm{Cu}$ in cupper flotation concentrates

$\mathrm{L}_{1}$ and $\mathrm{L}_{2} \quad$ Replicates of $\mathrm{L}_{\mathrm{Cu}}$ determination

LSD Least significant difference

p-value $\quad$ Real $\alpha$ value of a contrast

\section{REFERENCES}

Boucher, M. E., Chaala, A. And Roy, C. Bio-Oils Obtained by Vacuum Pyrolysis of Softwood Bark as a Liquid Fuel for Gas Turbines. Part 1: Properties of Bio Oil and its Blends with Methanol and Pyrolysis Aqueous Phase. Biomass \& Bioenergy, 19, p. 337 (2000).

Brossard, L. E., Cortez, L. A. B, Penedo M., O. E. And Bezzon G. Vacuum Distillation of Slow Pyrolysis Bagasse Bio Oil. Energy for Sustainable Development, IV (2), p. 51 ( 2000).

Brossard L. E And Cortez, L. A. B. Potential for the Use of Pyrolytic Bio Oil from Bagasse in Industry. Biomass \& Bioenergy, 12 (5), p. 363 (1997).

Chum, H. L. And Kreibich, R. E. Process for Preparing Phenolic Formaldehyde Resins Products Derived from Fractionated Fast Pyrolysis Oils, U.S. Patent 5091499 (1993). 
Diebold, J. P And Bridgwater, A. V. Overview of Fast Pyrolysis of Biomass for the Production of Liquid Fuels in Fast Pyrolysis of Biomass. A Handbook.; A. Bridgwater CPL Press, p. 14 (1999).

Diebold, J. And Scahill, J. Production of Primary Pyrolysis Oils in a Vortex Reactor" in Pyrolysis Oils from Biomass, Soltes, E. J., Milne, T. A. (eds). ACS Symposium Series 376; American Chemical Society, p. 31 (1988).

Lomax, J. A., Commandeur, J. M., Arisz, P.W. And Scott, D.S. Characterization of Oligomers and Sugarring-Cleavage Products in The Pyrolysate of Cellulose. J. Anal. Appl.. Pyrol. 19, p. 65 (1991).

Pakdel, H., Zhang H. G. And Roy, C. Detailed Characterization of Biomass Pyrolysis Oils .Polar Fractions. In Advances in Thermochemical Biomass Conversion, AV. Bridgwater, Blackie London, p. 1068 (1994).

Penedo, M. MSc. Thesis, Efluentes de la Pirolisis Lenta al Vacio del Bagazo de Caña de Azúcar, Universidad de Oriente, Santiago de Cuba, p 4550 (2000).

Radlein, D., Piskorz J. And Majerski, P. Method of Upgrading Pyrolysis Liquids for Use as Fuels and as a Source of Chemicals by Reaction with Alcohols, European Patent Appl. EP 0718392 (1996).
Radlein, D. The Production of Chemicals from Fast Pyrolysis Bio-Oils in Fast Pyrolysis of Biomass: A Handbook. A. Bridgwater, S. Czernik, J. Diebold, D. Méier, A. Oasmaa, C. Peacocke, J. Piskorz, D. Radlein. CPL Press, p. 164 (1999).

Roy, C., Blanchette, D., Korving, L., Yang, J. And De Caumia, B. Development of a Novel Vacuum Pyrolysis Reactor with Improved Heat Transfer Potential. In Bridgwater A.V., Boococks DGB. Developments in Thermochemical Biomass Conversion. London, UK: Blackie Academic and Professional, p. 351 (1997).

Shadix, C. R And Tennison, P. J. Effect of Char Content and Simple Additives on Biomass Pyrolysis Oil Droplet Combustion, $27^{\text {th }}$ Symposium (International) on Combustion, The Combustion Institute (1998).

Yorgun, S., Sensoz, S. and Kocar, M. Characterization of the Pyrolysis Oil Produced in the Slow Pyrolysis of Sunflower-Extracted Bagasse, Biomass \& Bioenergy, 20 p. 141 (2001).

Zhou, J., Oehr, K., Simons, G. And Barras, G. Simultaneous $\mathrm{NO}_{\mathrm{x}}$ and $\mathrm{SO}_{\mathrm{x}}$ Control Using BioLime $^{\mathrm{TM}}$ in Biomass Gasification and Pyrolysis, State of the Art and Future Prospects, K. Kalschmitt and A.V. Bridgwater, CPL Press, p. 490 (1997). 